\title{
Analysis of Erosion Hazard at Gagakan Sub-Watershed, Blora District, Central Java Province, Indonesia
}

\author{
Diah Auliyani*, Tyas Mutiara Basuki \\ Watershed Management Technology Center, \\ Jl. A. Yani - Pabelan, Kartasura PO BOX 295 Surakarta, Jawa Tengah \\ *Email: d_auliyani@yahoo.com
}

\begin{abstract}
Auliyani D, Basuki T M. 2017. Analysis of Erosion Hazard at Gagakan Sub-Watershed, Blora District, Central Java Province, Indonesia. Proc Internat Conf Sci Engin 1: 85-89. Availability of soil erosion data is crucial for recovering carrying capacity of a degraded watershed. This study aims to analyze the level of soil erosion hazard in Gagakan Sub-Watershed, located at the downstream of Solo Watershed. Slope steepness of this area vary from very steep at the upper part and flat at the downstream. The dominant land cover is teak forest which consists of young and old stands. The level of soil erosion hazard was calculated by USLE (Universal Soil Loss Equation) and then analyzed spatially using GIS (Geographic Information System). The degree of erosion hazard was classified into five classes, i.e very slight, slight, moderate, severe, and very severe. The results showed that erosion hazard level of Gagakan sub-watershed ranged from very slight to very severe. The dominant is very slight $(69 \%)$, while the others classified as slight (11\%), moderate (15\%), severe $(1 \%)$, and very severe $(4 \%)$. The countermeasures of soil erosion should be focused on the area with severe and very severe level of erosion hazard.
\end{abstract}

Keywords: Soil erosion, Teak forest, USLE

\section{INTRODUCTION}

As part of a watershed ecosystem, soil provides many valuable environmental goods and services, such as food, carbon sequestration, water regulations, and habitat provision (De Vente et al., 2013). Along with the population growth, the need for land resources is also increasing as well. Human intervention in the utilization of land resources beyond its carrying capacity may cause soil erosion (Eisazadeh, Sokouti, Homaee, \& Pazira, 2012; Gholami, 2013) which leads to decrease in land productivity and environmental degradation.

Soil erosion is becoming the main issue of watershed management (Baja, Ramli, \& Lias, 2009), which generate negatively effect not only in the erosion spot (on-site impact) but also in the downstream area (off-site impact) (Boardman, 2006). Its socio-economic negative impact and environmental degradation caused were seized the researcher and policy.

Availability of soil erosion data is crucial for recovering carrying capacity of a degraded watershed. Gagakan Sub-Watershed is the downstream area of Solo Watershed, one of the priority watersheds that the carrying capacity should be restored by forest and land rehabilitation (RHL) activities (Dirjen PDASHL, 2015). According to the background, this study aims to analyze the level of soil erosion hazard in Gagakan SubWatershed.

\section{MATERIALS AND METHODS}

\section{Study area}

This study was conducted in Gagakan Sub-Watershed of Blora District, Central Java Province. This area is the upper parts of Solo Watershed, extending from $111^{\circ} 30^{\prime} 34^{\prime \prime}$ to $111^{\circ} 35^{\prime} 52^{\prime \prime}$ East Longitude and $7^{\circ} 2^{\prime} 22^{\prime \prime}$ to $7^{\circ} 7^{\prime} 57^{\prime \prime}$ South Latitude. The administrative map of Gagakan Sub-Watershed is provided in Figure 1.

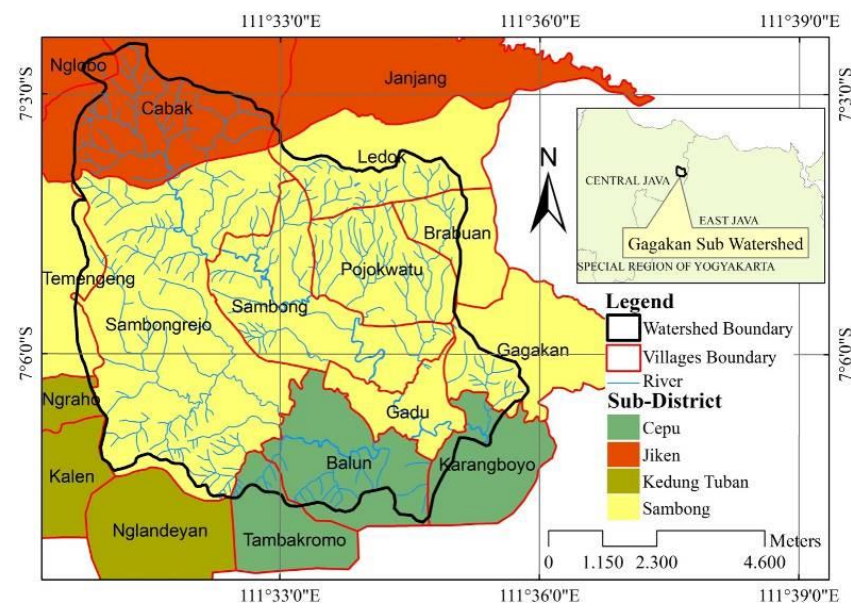

Figure 1. The administrative map of The Gagakan Sub-Watershed.

\section{Procedures}

The data used for analysis consists of (1) land cover maps derived from Google Imaginary, (2) soil map obtained from Regional Physical Planning Programme for Transmigration (RePPProT), (3) slope steepness generated from Digital Elevation Model (DEM) of Shuttle Radar Topographic Mission (SRTM) $(30 \mathrm{~m}$ resolution) acquired from Earth Explorer Database of United States Geological Survey (USGS), and (4) ground truth data obtained from field surveys. Rainfall data were collected from climatology stations of Watershed Management Technology Center. 


\section{Data analysis}

The erosion hazard level was analyzed spatially using Geographic Information Systems (GIS). Soil loss estimation calculated based on Universal Soil Loss Equation (USLE) (Wischmeier \& Smith, 1978):

$$
\mathrm{A}=\mathrm{R} \times \mathrm{K} \times \mathrm{LS} \times \mathrm{CP}
$$

Where:
A = Average annual soil loss per unit area (ton.ha- ${ }^{1}$.year ${ }^{-1}$ )
$\mathrm{R}=$ Rainfall erosivity factor
$\mathrm{K}=$ Soil erodibility factor
LS = Slope length and gradient factor
$\mathrm{CP}=$ Vegetation cover and management factor

\section{Rainfall Erosivity Factor}

The estimation method using maximum rainfall intensity for 30 minutes is the most accurate procedure (Widiatmaka \& Soeka, 2012). Therefore, the Bols equation (Bols, 1978) was applied to estimate rainfall erosivity.

$$
\mathrm{EI}=6,119 \times \mathrm{R}^{1,21} \times \mathrm{D}^{-0,47} \times \mathrm{M}^{0,53}
$$

Where:

$\mathrm{EI}=$ Rainfall erosivity $(\mathrm{KJ} / \mathrm{ha})$

$\mathrm{R}=$ Monthly rainfall $(\mathrm{cm})$

$\mathrm{D}=$ Average number of rainy days (day)

$\mathrm{M}$ = Maximum rainfall during 24 hours within the corresponding month $(\mathrm{cm})$

\section{Soil Erodibility Factor (K)}

Soil erodibility is defined as the degree of soil sensitivity to the kinetic energy of rainfall. The smoother texture of the soil, it will more easily erode (Herawati, 2010). The $\mathrm{K}$ value in this study was obtained from secondary data on soil type.

\section{Slope Length and Gradient Factor (LS)}

Digital elevation model were able to generate the accurate value of slope steepness (Hrabalíková \& Janeček, 2016). In this study, to calculate the LS value, DEM were classified into five classes, i.e. $<5 \%,>5-15$ $\%,>15-35 \%,>35-50 \%$, and $>50 \%$. The LS value is presented in Table 1.

Table 1. Length and slope (LS) values.

\begin{tabular}{ccl}
\hline No & Slope classes & LS value \\
\hline 1. & $<5 \%$ & 0,25 \\
2. & $>5-15 \%$ & 1,20 \\
3. & $>15-35 \%$ & 4,25 \\
4. & $>35-50 \%$ & 9,50 \\
5. & $>50 \%$ & 12,00 \\
\hline Source: (BPDASPS 2011$)$ &
\end{tabular}

4. Vegetation Cover and Management Factor (CP) The value of vegetation and management factor in this study were obtained from Java erosion model (Ministry of Public Work, 2012) as presented in Table 2.

Table 2. The value of vegetation cover and land management (CP).

\begin{tabular}{clllll}
\hline \multirow{2}{*}{ No } & \multirow{2}{*}{ Land cover } & \multicolumn{3}{c}{ Slope Classes / CP Value } \\
\cline { 3 - 5 } & & $0-2 \%$ & $2-15 \%$ & $15-40 \%$ & $>40 \%$ \\
\hline 1. & Settlement & 0,0500 & 0,0500 & 0,0500 & 0,0500 \\
2. & Paddy field & 0,0100 & 0,0100 & 0,0100 & 0,0250 \\
3. & Dry land agriculture & 0,0445 & 0,0625 & 0,0955 & 0,1365 \\
4. & Estate & 0,0045 & 0,0104 & 0,0199 & 0,0338 \\
5. & Mixed garden & 0,0223 & 0,0313 & 0,0478 & 0,0683 \\
6. & Natural forest & 0,0002 & 0,0005 & 0,0010 & 0,0010 \\
7. & Production forest & 0,0010 & 0,0010 & 0,0020 & 0,0020 \\
8. & Shrubs & 0,0010 & 0,0015 & 0,0020 & 0,0020 \\
9. & Grass land & 0,0050 & 0,0100 & 0,0200 & 0,0200 \\
10. & Bare land & 1,0000 & 1,0000 & 1,0000 & 1,0000 \\
\hline Source $:$ Ministry of Public Work, 2012) & & & &
\end{tabular}

The results of the soil loss calculation then classified into five classes according to decree No P.7/DAS-V/2011 presents in Table 3.

\begin{tabular}{|c|c|c|c|c|c|c|}
\hline \multirow[b]{2}{*}{ No } & \multirow[b]{2}{*}{ Soil Solum (cm) } & \multicolumn{5}{|c|}{ Erosion Hazard Classes } \\
\hline & & $\begin{array}{c}\mathrm{I} \\
<15 \mathrm{ton} / \mathrm{ha} / \text { year }\end{array}$ & $\begin{array}{c}\text { II } \\
15-60 \text { ton/ha/year }\end{array}$ & $\begin{array}{c}\text { III } \\
60-180 \text { ton/ha/year }\end{array}$ & $\begin{array}{c}\text { IV } \\
180-480 \text { ton/ha/year }\end{array}$ & $\begin{array}{c}\mathrm{V} \\
>480 \text { ton/ha/year }\end{array}$ \\
\hline 1 & $>90$ & Very slight & Slight & Moderate & Severe & Very severe \\
\hline 2 & $60-90$ & Slight & Moderate & Severe & Very severe & Very severe \\
\hline 3 & $30-60$ & Moderate & Severe & Very severe & Very severe & Very severe \\
\hline 4 & $<30$ & Severe & Very severe & Very severe & Very severe & Very severe \\
\hline
\end{tabular}

Table 3. Erosion hazard classification 


\section{RESULTS AND DISCUSSION}

The average monthly rainfall in Gagakan SubWatershed during 2016 was $167 \mathrm{~mm}$, with the average number of rainy days was 17 days, and maximum rainfall during 24 hours was $53 \mathrm{~cm}$. The highest rainfall was occurred in November while the lowest rainfall occurred in August (Figure 2).

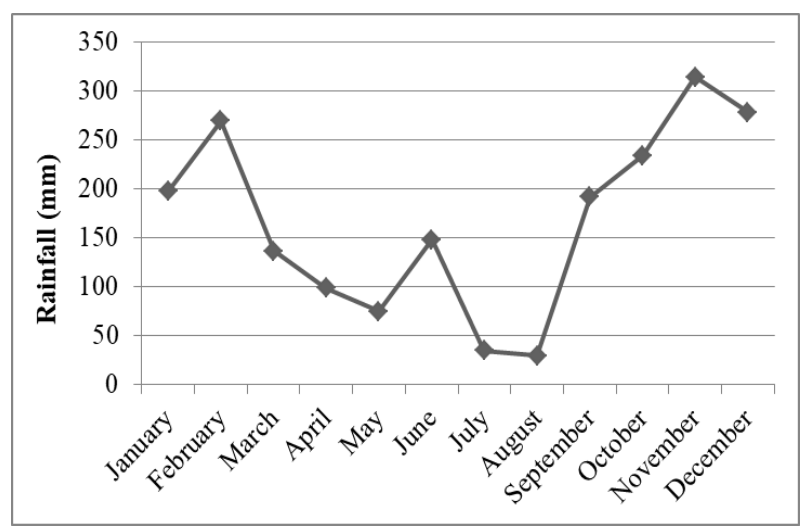

Figure 2. Monthly rainfall of Gagakan Sub-Watershed in 2016.

The soil types of Gagakan Sub-Watershed consists of tropudalf $(73,2 \%)$ and eutropepts $(26,8 \%)$. According to the secondary data of soil types, $\mathrm{K}$ value of tropudalf is 0,23 (Undang \& Suwardjo, 1984), while eutropepts is 0,29 (Hamer, 1980).

Topography of Gagakan Sub-Watershed vary from very steep at the upper part and flat at the downstream. Analysis of DEM (USGS, 2015) showed that the dominant slope steepness in this area sequentially were sloping (33\%), moderately slope $(27 \%)$, flat $(24 \%)$, steep (13\%), and very steep (3\%) (Figure 3).

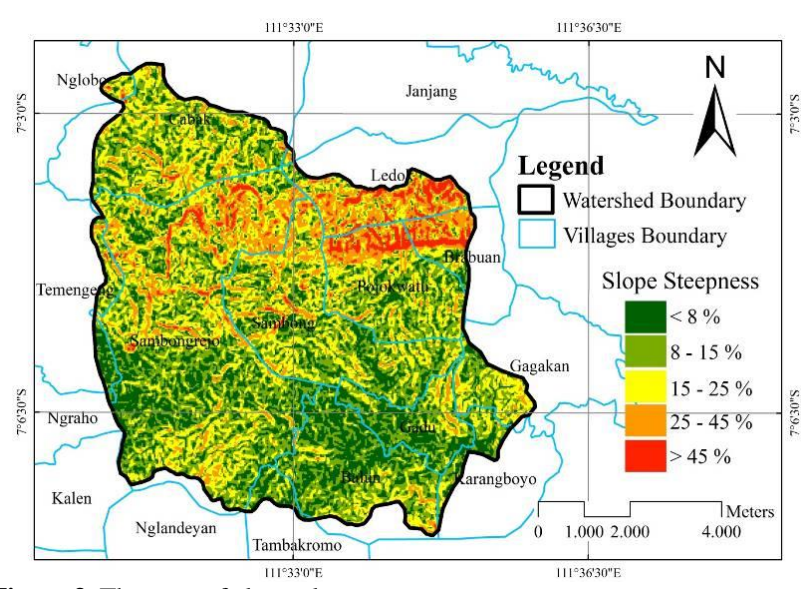

Figure 3. The map of slope classes.

Satellite image from Google Earth 2014 and ground checks in 2016 were used to classify the existing land cover of the study area. The dominant land cover is teak forest which consists of old (53\%) and young (23\%) stands, and dryland agriculture (20\%). Spatial distribution of existing land cover of Gagakan SubWatershed is provided in Figure 4.

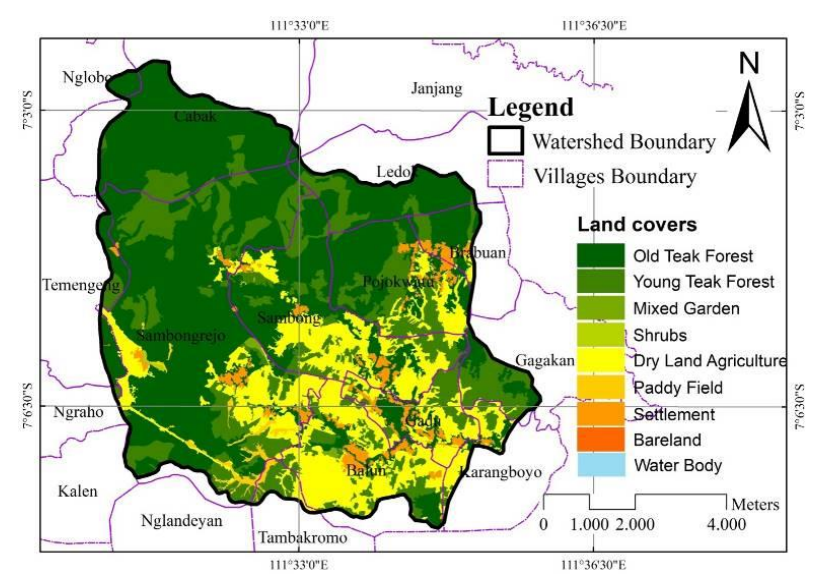

Figure 4. The map of land cover.

Erosion prone are the potential areas for soil erosion. Most of the study area categorized as very slight level of erosion vulnerability (69\%). Spatially distribution of erosion hazard in the Gagakan Sub-Watershed is presented in Figure 5, while the administrative distribution is provided in Table 4 .

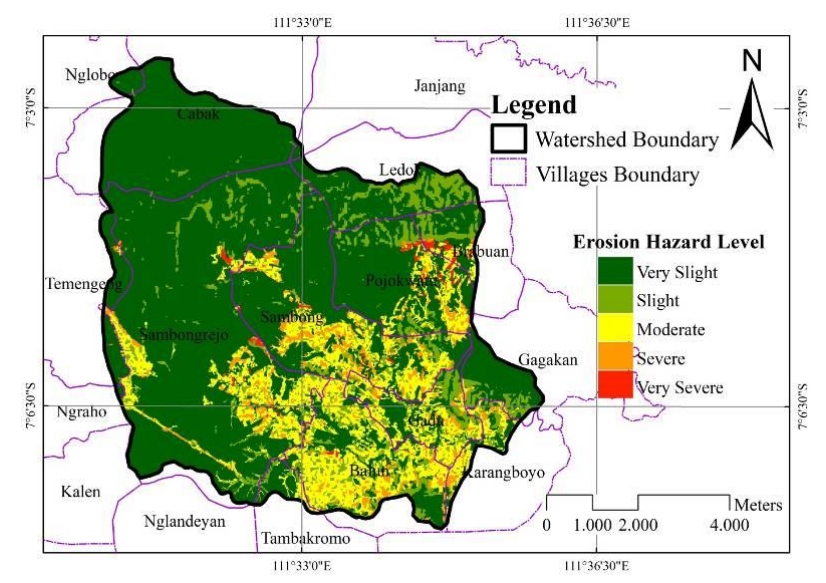

Figure 5. The spatial distribution of erosion hazard level at Gagakan SubWatershed.

Spatially, both of severe and very severe of erosion hazard classes occurred in bare land, settlement, and dry land agriculture area. In the study area, dry land agriculture area was generally planted with corn with fewer ground plants. Therefore, the soil will be more susceptible to the kinetic energy of rainfall and lead to potentially higher soil loss. The countermeasures of soil erosion should be focused on the area with severe and very severe level of erosion hazard. 
Table 4. The administrative distribution of erosion hazard level.

\begin{tabular}{|c|c|c|c|c|c|}
\hline \multirow{2}{*}{ Sub-Districts/ Villages } & \multicolumn{5}{|c|}{ Area (Ha) } \\
\hline & Very Slight & Slight & Moderate & Severe & Very Severe \\
\hline Cepu & 248,95 & 156,67 & 342,55 & 3,49 & 66,60 \\
\hline Balun & 172,52 & 122,77 & 283,15 & 3,46 & 52,32 \\
\hline Karangboyo & 31,72 & 22,33 & 47,03 & 0,03 & 13,65 \\
\hline Tambakromo & 44,71 & 11,57 & 12,37 & - & 0,63 \\
\hline Jiken & 793,19 & 4,52 & - & - & - \\
\hline Cabak & 755,97 & 3,83 & - & - & - \\
\hline Janjang & 6,50 & 0,19 & - & - & - \\
\hline Nglobo & 30,72 & 0,50 & - & - & - \\
\hline Kedung Tuban & 3,96 & $\mathbf{0 , 0 0}$ & - & - & - \\
\hline Kalen & 0,04 & - & - & - & - \\
\hline Nglandeyan & 0,08 & - & - & - & - \\
\hline Ngraho & 3,84 & 0,00 & - & - & - \\
\hline Sambong & 3435,75 & 528,97 & 623,66 & 42,13 & 206,11 \\
\hline Brabuan & 84,83 & 38,23 & 16,96 & 9,54 & 3,98 \\
\hline Gadu & 102,94 & 73,43 & 113,09 & 1,29 & 22,09 \\
\hline Gaggakan & 145,34 & 30,30 & 4,49 & - & 2,00 \\
\hline Ledok & 222,02 & 97,91 & - & - & - \\
\hline Pojokwatu & 417,01 & 60,29 & 73,17 & 13,09 & 30,66 \\
\hline Sambong & 566,94 & 79,88 & 198,93 & 5,82 & 88,38 \\
\hline Sambongrejo & 1788,00 & 147,97 & 214,45 & 11,46 & 58,22 \\
\hline Temengeng & 108,67 & 0,97 & 2,58 & 0,95 & 0,76 \\
\hline Total & 4481,85 & 690,16 & 966,21 & 45,63 & 272,70 \\
\hline Percentage (\%) & 69 & 11 & 15 & 1 & 4 \\
\hline
\end{tabular}

\section{CONCLUSIONS}

The results of this study showed that erosion hazard level at Gagakan sub-watershed ranged from very slight to very severe. The dominant is very slight $(69 \%)$, while the others classified as slight (11\%), moderate $(15 \%)$, severe $(1 \%)$, and very severe (4\%). The countermeasures of soil erosion should be focused on the area with severe and very severe level of erosion hazard.

\section{ACKNOWLEDGEMENTS}

This research was funded by Watershed Management Technology Center, Surakarta.

\section{REFERENCES}

Baja, S., Ramli, M., \& Lias, S. A. (2009). Spatial-based assessment of land use, soil erosion, and water protection in the Jeneberang valley, Indonesia. Biologia, 64(3), 522-526. https://doi.org/10.2478/s11756-009-0074-y

Boardman, J. (2006). Soil erosion science: Reflections on the limitations of current approaches B. Catena, 68, 73-86. https://doi.org/10.1016/j.catena.2006.03.007

Bols, P. (1978). The Iso-Erodent Map of Java and Madura. Bogor: Soil Res. Inst.

BPDASPS. (2011). Surat Keputusan BPDASPS Nomor P.7/DASV/2011 Tentang Petunjuk Teknis Sistem Standar Iperasi Prosedur (SSOP) Penanggulangan Banjir dan Tanah Longsor. Jakarta: Sekretariat Ditjen.

De Vente, J., Poesen, J., Verstraeten, G., Govers, G., Vanmaercke, M., Van Rompaey, A., ... Boix-Fayos, C.
(2013). Predicting soil erosion and sediment yield at regional scales: Where do we stand? Earth-Science Reviews, 127, 1629. https://doi.org/10.1016/j.earscirev.2013.08.014

Dirjen PDASHL. (2015). Peraturan Dirjen PDASHL Nomor P.10/PDASHL-SET/2015 Tentang Rencana Strategis Direktorat Jenderal Pengendalian Daerah Aliran Sungai dan Hutan Lindung Tahun 2015-2019. Jakarta: Sekretariat Ditjen PDASHL.

Eisazadeh, L., Sokouti, R., Homaee, M., \& Pazira, E. (2012). Comparison of empirical models to estimate soil erosion and sediment yield in micro catchments. Eurasian Journal of Soil Science, $1, \quad 28-33 . \quad$ Retrieved from http://fesss.org/eurasian_journal_of_soil_science.asp

Gholami, V. (2013). The influence of deforestation on runoff generation and soil erosion (Case study: Kasilian Watershed). Journal of Forest Science, 59(7), 272-278.

Hamer, W. (1980). Soil Conservation Consultant Report. Technical Note No.7, FAO Project INS/78/006. Bogor: Centre for Soil Research.

Herawati, T. (2010). Analisis Spasial Tingkat Bahaya Erosi di Wilayah DAS Cisadane Kabupaten Bogor. Jurnal Penelitian Hutan Dan Konservasi Alam, VII(4), 413-424.

Hrabalíková, M., \& Janeček, M. (2016). Comparison of different approaches to LS factor calculations based on a measured soil loss under simulated rainfall. Soil and Water Research, 2017(1), 1-9. https://doi.org/10.17221/222/2015-SWR

Ministry of Public Work. (2012). Java Erosion Model - USLE 30m: Application of the Universal Soil Loss Equation. Institutional Strenghthening for Integrated Water Resources Management (IWRM) in the 6 CI's River Basin Territory.

Undang, K., \& Suwardjo, H. (1984). Kepekaan erosi beberapa jenis tanah di Jawa menurut metode USLE. Pemberitaan Penelitian Tanah Dan Pupuk, 3, 17-20.

USGS. (2015). Geological Survey. Retrieved from http://earthexplorer.usgs.gov

Widiatmaka, \& Soeka, B. D. G. (2012). Distribusi Spasial Besaran Erosi Untuk Perencanaan Peggunaan Lahan Lestari : 
Studi Kasus Unit Pemukiman Transmigrasi ( UPT ) Rantau Pandan SP-1, Provinsi Jambi. Globe, 14(1), 60-69.
Wischmeier, W. H., \& Smith, D. (1978). Predicting rainfall erosion losses: a guide to conservation planning. USDA Agriculture Handbook No. 537. 
THIS PAGE INTENTIONALLY LEFT BLANK 